\title{
Efektivitas Penilaian Sertifikasi Guru Kelas MI melalui Kegiatan PLPG Kuota Tambahan Tahun 2013
}

\author{
Sutrisno \\ MI Suryawiyyah Kirig Mejobo Kudus \\ sutrisnouzy@gmail.com \\ DOI: 10.18326/mudarrisa.v8i2.283-312
}

\begin{abstract}
Abstrak
Tulisan ini bertujuan untuk memaparkan tentang evektivitas penilaian sertifikasi guru kelas MI melalui kegiatan PLPG. Penelitian ini menggunakan metode deskriptif analitis dengan mengkaji referensi yang bersumber dari perpustakaan. Dalam penelitian ini didapatkan beberapa kesimpulan kesimpulan: pertama, proses dan intstrumen penilaian sertifikasi guru kelas MI melalui PLPG pada guru kelas MI se-kecamatan Mejobo kabupaten Kudus yang telah mengikuti PLPG sudah terlaksanakan dengan baik dan sesuai dengan peraturan pemerintah; kedua, pandangan guru kelas MI se-kecamatan Mejobo kabupaten Kudus yang telah mengikuti PLPG terhadap penilaian sertifikasi guru kelas MI melalui PLPG sudah baik, karena banyak guru yang pada awal datangnya terlihat pasif kemudian menjadi aktif dan kreatif; ketiga, ketercapaian penilaian sertifikasi guru melalui kegiatan PLPG dapat dilihat melalui meningkatnya motivasi para guru dalam mengajar, membangun mental positif para guru dalam melaksanakan pembelajaran, meningkatkan kompetensi guru, guru terdidik melaksanakan tugas dengan sepenuh hati, dan guru dapat melaksanakan pembelajaran aktif; keempat, kurang efektifnya penilaian sertifikasi guru melalui kegiatan PLPG di LPTK Rayon 232 IAIN terkendala pada sisi teknis waktu pelaksanaan PLPG yang singkat sehingga berimbas pada kedalaman pemahaman guru terhadap materi yang diberikan.
\end{abstract}


This paper aims to describe the effectiveness of assessment of MI (Madrasah Ibtidaiyah: Indonesian State Islamic Primary School) teacher certification through PLPG activities. This research uses descriptive analytical method to assess references from the library. In this study, as the first conclusion, the processes and the assessment instrument of certification in PLPG LPTK Rayon 232 IAIN Surakarta (additional quota of 2013) for the teachers of District Mejobo, Kudus has properly fulfilled the standard in accordance with the regulations and operational guidelines as directed by the government. Secondly, from the teachers' point of view, the assessment of MI teachers certification through PLPG is already good because many teachers look passive initially then becomes active and creative at last. Thirdly, the assessment of teacher achievement, to be certified through PLPG activities, basically aims to increase the motivation of teachers in their teaching implementation. Fourthly, the ineffective assessment of teacher certification through PLPG is due to the "short time" (the length of time) allotted for the PLPG which brings about the effect on the deepness of the teachers' understanding on the materials supplied.

Kata kunci: penilaian, sertifikasi, PLPG

\section{Pendahuluan}

Pendidikan merupakan sebuah rangkaian proses pemberdayaan manusia menuju kedewasaan, baik secara akal, mental, maupun moral, untuk menjalankan fungsi kemanusiaan yang diemban sebagai hamba dihadapan Tuhan-Nya dan sebagai pemimpin (khalifah) di bumi (Tafsir, 1994:15). Oleh karena itu, fungsi utama pendidikan adalah mempersiapkan peserta didik sebagai generasi penerus bangsa dengan kemampuan dan keahlian (skill) yang diperlukan agar memiliki kemampuan dan kesiapan untuk terjun ketengah masyarakat (Nawawi, 1995:26). 
Pendidikan merupakan pilar bagi kehidupan suatu bangsa. Pendidikan memberikan kontribusi yang sangat besar terhadap kemajuan suatu bangsa dan merupakan wahana dalam menerjemahkan pesan-pesan konstitusi serta sarana dalam membangun watak bangsa. Masyarakat yang cerdas dan memberi nuansa kehidupan yang cerdas pula, dan secara progresif akan membentuk kemandirian. Masyarakat bangsa yang demikian merupakan investasi besar untuk berjuang keluar dari krisis dan siap menghadapi globalisasi (Mulyasa, 2002:4).

Selain itu, pendidikan memegang peranan yang besar dalam peningkatan kualitas sumber daya manusia. Peningkatan sumber daya manusia merupakan suatu proses peningkatan kualitas (mutu) pendidikan nasional kita, baik di sekolah negeri maupun swasta. Dari beberapa lembaga pendidikan yang ada, baik negeri maupun swasta memiliki sejumlah masalah, salah satunya adalah rendahnya mutu pendidikan pada setiap jenjang pendidikan, ini dikarenakan masih banyak pendidik yang sudah berusia lanjut dan berpendidikan yang belum memenuhi syarat sebagai pendidik terutama secara akademik dan tidak menguasai teknologi, selain itu ketersediaan media pembelajaran yang belum memenuhi prasyarat dan belum terpenuhinya standar kompetensi pendidik dan tenaga kependidikan, khususnya jenjang pendidikan dasar dan menengah (Mastuhu, 2004:10). Berdasarkan Survey United Nations Educational, Scientific and Cultural Organization (UNESCO), terhadap kualitas pendidikan di Negara-negara berkembang di Asia Pacific, Indonesia menempati peringkat 10 dari 14 negara. Sedangkan untuk kualitas para guru, kulitasnya berada pada level 14 dari 14 negara 
berkembang (Faisal, Jalal, Dedi, 2001:59). Salah satu faktor rendahnya kualitas pendidikan di Indonesia adalah karena lemahnya para guru dalam menggali potensi anak. Para pendidik seringkali memaksakan kehendaknya tanpa pernah memperhatikan kebutuhan, minat dan bakat yang dimiliki siswanya. Kelemahan para pendidik kita, mereka tidak pernah menggali masalah dan potensi para siswa. Pendidikan seharusnya memperhatikan kebutuhan anak bukan malah memaksakan sesuatu yang membuat anak kurang nyaman dalam menuntut ilmu. Proses pendidikan yang baik adalah dengan memberikan kesempatan pada anak untuk kreatif. Semua ini dikarenakan kurangnya profesionallisme para guru ditambah pendidikan yang tidak memenuhi syarat sebagai pendidik

Problem pendidik yang lain, yaitu masih banyak pendidik yang berpenghasilan dibawah standar sehingga banyak guru yang melakukan kerja sampingan selain mengajar, atau mengajar diberbagai tempat yang berbeda-beda instansi, hal ini terkadang mengorbankan salah satunya dan secara langsung mengorbankan juga peserta didik, karena harus belajar dikelas tanpa dampingan guru (Zamroni, 2000:21).

Berkaitan dengan upaya peningkatan kualitas pendidikan, maka kunci peningkatan kualitas adalah keberadaan pendidik dan tenaga pendidikan (Faisal, Jalal, Dedi, 2001:59). Dalam pendidikan, pendidik merupakan kunci dalam peningkatan kualitas pendidikan dan pendidik berada pada posisi yang strategis bagi upaya reformasi pendidikan yang berorientasi pada pencapaian kualitas. Apapun upaya yang dilakukan dalam peningkatan mutu pendidikan dalam sebuah sistem sekolahan akan menjadi titik yang berarti jika disertai oleh adanya pendidik profesional 
secara pedagogik maupun akademik (Surya, 2000:1). Oleh karena itu, setiap upaya untuk membenahi dan meningkatkan kualitas pendidikan harus melibatkan penataan dan pemberdayaan guru.

Upaya ke arah peningkatan profesionalisme guru menjadi satu hal yang sangat urgen untuk dilaksanakan dalam penataan guru dan tenaga kependidikan. Karena hanya dengan sikap profesional yang dicirikan dengan adaya otonomi, keahlian yang memadai, komitmen guru yang tinggi terhadap tugas dan adanya semangat untuk meningkatkan kemampuan secara berkelanjutan dalam hal akademik dan pedagogik, guru akan bisa memberikan kontribusinya yang berarti bagi upaya perbaikan kualitas pendidikan nasional. Dalam kerangka penataan dan pemberdayaan terhadap guru inilah dibutuhkan strategi yang tepat agar para guru dapat benar-benar trampil secara lebih profesional dalam mengemban tugasnya dan meningkatkan penghasilan guru (Azra, 2002:22).

Salah satu upaya pemerintah dalam menjawab kebekuan tentang peningkatan dan pembentukan guru yang profesional dengan bersertifikat formal adalah melalui penyempurnaan sejumlah regulasi bersama-sama dengan DPR (Dewan Perwakilan Rakyat). Salah satu regulasi yang telah dihasilkan adalah Undang-undang RI Nomor 14 tahun 2005 tentang Guru dan Dosen. Guru terlebih dahulu diharuskan memenuhi sejumlah persyaratan agar mencapai standar minimal seseorang yang berprofesi sebagai guru yang profesional (UU, 2005:10). Demikian pula Pasal 8 dalam Undang-undang guru dan dosen dinyatakan bahwa pengakuan terhadap guru sebagai tenaga profesional akan diberikan jika guru yang 
bersangkutan telah memiliki sejumlah syarat, antara lain adalah kualifikasi akademik, kompetensi, dan sertifikat pendidik yang disyaratkan.

Salah satu pasal (Pasal 8) dalam Undang-undang Guru dan Dosen dinyatakan bahwa pengakuan terhadap guru sebagai tenaga profesional akan diberikan jika guru yang bersangkutan telah memiliki sejumlah syarat, antara lain adalah kualifikasi akademik, kompetensi, dan sertifikat pendidik yang disyaratkan. Kualifikasi akademik yang dimaksud harus diperoleh melalui pendidikan tinggi program sarjana (S1) atau diploma empat (D4). Kompetensi guru yang dimaksud dalam undang-undang ini adalah kompetensi pedagogik, kompetensi kepribadian, kompetensi profesional, dan kompetensi sosial. Sementara sertifikat pendidik diperoleh guru yang bersangkutan melalui pendidikan profesi yang diikutinya (Pemerintah Republik Indonesia, 2005:12).

Lahirnya undang-undang tentang guru dan dosen tersebut mewajibkan guru untuk menjadi tenaga profesional dalam bidangnya. Profesionalisme guru diwujudkan dengan adanya sertifikasi, karena menurut undang-undang tersebut seluruh guru harus memiliki sertifikat pendidik melalui pendidikan profesi. Menurut Peraturan Pemerintah No.74/2008 Tentang Guru, bagi guru dalam jabatan, pengembangan profesi guru atau sertifikasi guru dilakukan dengan dua cara yaitu: 1) portofolio; dan 2) pendidikan latihan profesi guru (PP No.74/2008 Tentang Guru, 2008:43). Dari data Depdiknas Program sertifikasi yang dilakukan sejak Tahun 2007 sudah mencapai sasaran 40\% dan pada tahun 2014 diharapkan 100\% guru sudah tersertifikasi (Ditjen, 2009:29). 
Pada awal pelaksanaan, sertifikasi dilaksanakan dengan cara portofolio, apabila secara portofolio dinyatakan sudah lulus maka seorang pendidik/tenaga kependidikan tidak perlu mengikuti PLPG. Akan tetapi, apabila dinyatakan portofolionya belum memenuhi ketentuan maka pendidik/tenaga kependidikan yang bersangkutan harus mengikuti PLPG. Mulai tahun 2012 pelaksanaan program sertifikasi guru dilaksanakan secara langsung melalui PLPG yang dilaksanakan oleh para lembaga yang berkaitan dengan sertifikasi guru, misalnya LPTK tertentu yang telah ditunjuk pemerintah.

Program sertifikasi guru yang dilakukuan melalui PLPG memberikan nuansa baru sebagai suatu pelatihan profesionalisme. Namun dari pelaksanaan program PLPG tersebut masih perlu dikritisi dari berbagai kegiatan yang ada dalam pelaksanaanya, terutama penilaian atau penilain terhadap guru tersertifikasi melalui PLPG sehingga bisa mendapat guru bersertifikat profesional.

Kemungkinan belum atau sudah efektifnya kegiatan PLPG menjadi cara penilaian sertifikasi guru, mengundang peneliti untuk menelaahnya. Sebagaimana diketahui bahwa tujuan Diklat Profesi Guru ini antara lain adalah menjadikan peserta menyadari penting dan strategisnya kedudukan guru dalam berbagai aspek kehidupan; memiliki sikap positif terhadap profesi guru dan tenaga kependidikan lainnya dalam pengelolaan pendidikan; mempunyai komitmen, dedikasi, dan integritas yang tinggi terhadap profesi guru sebagai pendidik; termotivasi untuk senantiasa mengembangkan kompetensi dirinya dalam bidang pendidikan 
dan atau bidang-bidang lain yang relevan dengan dunia pendidikan (Makruf, 2013:iii).

Adapun karakteristik bahan ajar sebagai panduan inti kegiatan diklat adalah modul, sedangkan bahan ajar lainnya diserahkan kepada instruktur disesuaikan dengan kebutuhan. Instruktur dapat menambahkan materi tambahan jika diperlukan sesuai dengan kebutuhan; Diharapkan bahan ajar dikaitkan fenomena-fenomena sehari-hari dan pengetahuan dan atau pengalaman peserta sebagai guru; Instruktur dapat mengelompokkan peserta ke dalam beberapa kelompok kecil diskusi jika dipandang perlu untuk kepentingan efektivitas materi bahan ajar; Ketercapaian bahan ajar diukur melalui kegiatan evaluasi selama kegiatan berlangsung dan pada akhir kegiatan.

Dengan tujuan yang cukup jelas dan didukung oleh bahan ajar yang disusun oleh ahlinya diharapkan bahwa PLPG membawa dampak yang nyata bagi guru untuk memperbaiki dan meningkatkan profesinya (Makruf, 2013:iii). Akan tetapi peralihan dari portofolio menjadi PLPG langsung dalam membentuk guru bersertifikat profesional/guru sertifikasi tidak lepas dari permasalahan. Diantaranya sistem penilaian yang diberikan masih perlu disempurnakan dan waktu 10 hari dalam melaksanakan PLPG merupakan waktu yang pendek untuk mencetak seseorang menjadi orang yang benar-benar profesional apalagi berkepribadian unggul, sehingga pencapaian secara maksimal kegiatan PLPG untuk mensertifikasi guru masih kabur dan semua ini tidak menjamin penilaian yang diberikan kepada guru dapat dilaksanakan 
dengan maksimal. Artinya, bisa jadi pelaksanaan penilaian sertifikasi guru melalui kegiatan PLPG kurang efektif.

Berdasarkan permasalahan dan fakta-fakta yang telah dihadirkan di atas, perlu diambil langkah untuk mengkajinya melalui penelitin dengan mengangkat tema "Efektifitas Penilaian Sertifikasi Guru Kelas MI Melalui Kegiatan PLPG Di LPTK Rayon 232 IAIN Surakarta Kuota Tambahan Tahun 2013." Penelitian ini dilakukan untuk mengetahui kurang efektifnya penilaian sertifikasi guru kelas MI melalui PLPG pada guru kelas MI se-kecamatan Mejobo yang mengikuti sertifikasi kuota tambahan tahun 2013.

\section{Metode Penelitian}

Penelitian ini bersifat kualitatif dengan pendekatan fenomenologis, dengan asumsi dasar bahwa objek ilmu tidak sebatas pada yang empirik, tetapi mencakup fenomena yang tidak lain dari pada persepsi, pemikiran, kemauan, dan keyakinan, subjek tentang sesuatu di luar subjek, ada yang transenden di samping aposteriorik (Muhadjir, 1996:12).

Pendekatan fenomenologi berlandaskan pada empat kebenaran, yaitu kebenaran empirik sensual yang jangkauannya yaitu segala kebenaran yang dapat terlihat oleh panca indra/yang bersifat indrawi, kebenaran empirik logik yang jangkauannya yaitu segala kebenaran yang dapat dinalar oleh akal/pemikiran, kebenaran empirik etik yang jangkauannya yaitu segala kebenaran yang berdasarkan pada benar, salah, baik, buruk, dan tanggung jawab, dan kebenaran empirik transenden yang jangkauannya yaitu segala kebenaran yang didasarkan 
pada aturan-aturan yang ditetapkan Tuhan atau bersifat transenden. Atas dasar cara mencapai kebenaran ini, fenomenologi menghendaki kesatuan antara subyek peneliti dengan pendukung obyek penelitian (Muhadjir, 1996:13).

Dalam metodologi fenomenologi, pada dasarnya hanya mengenal dua metode pengumpulan data yaitu observasi partisipan dan wawancara bebas. Akan tetapi sebagaimana menurut Guba dan Lincoln yang dikutip Moleong dapat mengggunakan dokumentasi sebagai metode tambahan (Muhadjir, 1996:13). Analisis dilakukan atas data yang ditemukan di lapangan, dan bukan sebagai upaya untuk menguji teori yang telah ditetapkan sebelumnya, mengingat bahwa penelitian kualitatif menolak pra-konsep sebelum terjun di lapangan (Muhadjir, 1996:166). Teknik analisis dalam penelitian ini menggunakan pendekatan induksi analitik. Data yang dikumpulkan kemudian dianalisis secara induksi untuk mengembangkan model deskripsi penelitian dan menghasilkan laporan deskripsi analitik.

\section{Pembahasan}

\section{Pelaksanaan PLPG Guru Kelas MI}

Dalam melaksanakan kegiatan PLPG, LPTK Rayon 232 FITK IAIN Surakarta memiliki dasar yang kuat sebagai pijakan pelaksanaan tutur pak Giyoto selaku ketua LPTK Rayon 232, kemudian imbuhnya penilaian Sertifikasi melalui PLPG bagi guru merupakan upaya meningkatkan profesionalitas guru yang diselenggarakan berdasarkan landasan hukum. Adapun dasar pijakan landasan hukum yang digunakan 
LPTK Rayon 232 FITK IAIN Surakarta dalam menyelenggarakan kegiatan PLPG sebagai penilaian sertifikasi guru itu antara lain: Undangundang RI Nomor 20 tahun 2003 tentang sistem pendidikan nasional, undang-undang RI nomor 14 tahun 2005 tentang Guru dan Dosen, peraturan Pemerintah RI Nomor 19 Tahun 2005 tentang Standar Nasional Pendidikan, peraturan Pemerintah RI Nomor 74 Tahun 2008 Tentang Guru, Peraturan Menteri Pendidikan Nasional Nomor 16 Tahun 2005 tentang Standar Kualifikasi dan Kompetensi Pendidik, Peraturan Menteri Pendidikan dan Kebudayaan Republik Indonesia Nomor 5 Tahun 2012 tentang Sertifikasi bagi Guru Dalam Jabatan, Keputusan Menteri Pendidikan Nasional Nomor 128/P/2013 tentang Penetepan Perguruan Tinggi Penyelenggara Sertifikasi Guru Dalam Jabatan, Keputusan Direktur Jendral Pendidikan Islam Nomor 2313 Tahun 2013 tentang Penetapan Peserta Sertifikasi Bagi Guru RA/Madrasah Dalam Jabatan Untuk Mata Pelajaran Qur'an Hadits, Akidah Akhlak, Fiqih, SKI, Bahasa Arab, Guru Kelas RA, Dan Guru Kelas MI (Kuota Tambahan) tahun 2013 (Giyoto, Wawancara Tentang Pelaksanaan PLPG Guru Kelas MI, 2014).

Kemudian menurut Hafidah selaku wakil ketua pelaksana kegiatan PLPG menambahkan bahwa dalam pelaksanaan PLPG di LPTK Rayon 232 juga menanamkan kepada semua peserta PLPG guru kelas MI untuk melakukan tugas sepenuh hati, penuh dengan ketulusan dan kesabaran dalam menghadapi hitrogenitas kemampuan, sikap dan prilaku para peserta didik (murid). Imbuhnya, hal ini diterapkan pada waktu para peserta melakukan Peer Teaching (Ujian Praktik), dimana para peserta 
yang berperan sebagai murid/peserta didik diperbolehkan bersikap selayaknya murid sesuai kelas yang dipilih oleh pesrta yang melakukan praktik (kelas 1 atau kelas 4) (Hafidah, Wawancara Tentang Pelaksanaan PLPG Guru Kelas MI, 2014).

\section{Tujuan}

PLPG memiliki tujuan: a) menghasilkan pendidik yang profesional, kompetitif, berbudaya, dan berkarakter Islam; b) menghasilkan temuantemuan inovatif dalam bidang kependidikan melalui kegiatan PTK; c) menghasilkan layanan pembelajaran yang baik kepada peserta didik; d) dapat mewujudkan suasana interaksi pembelajaran yang Islami dan berbudaya yang mendukung pembentukan karakter dan kompetensi lulusan (Giyoto, 2014).

\section{Peserta}

Peserta yang mengikuti PLPG tahun 2013 pada LPTK Rayon 232 FITK IAIN Surakarta berjumlah 2200 guru, dan 1300 guru merupakan guru kelas MI sedangkan 900 guru lainnya merupakan 500 guru kelas RA dan 400 guru Mapel. Peserta PLPG di LPTK Rayon 232 FITK IAIN Surakarta tahun 2013 yang berjumlah 2200 guru berasal dari berbagai kabupaten/kota di Propinsi Jawa Tengah, antara lain, Pekalongan, Batang, Banyumas, Purbalingga, Cilacap, Boyolali, Sukoharjo, Sragen, Grobogan, Jepara, Kudus, Pati, Rembang, dan Blora (Makruf, 2014).

\section{Proses Kegiatan PLPG}


Pelaksanaan PLPG guru kelas MI kuota tambahan tahun 2013 di LPTK Rayon 232 FITK IAIN Surakarta, secara keseluruhan kegiatan PLPG dilaksanakan 6 (enam) tahap dimulai akhir bulan Agustus hingga awal November, dengan menggunakan fasilitas tempat 4 hotel di Surakarta, antara lain: hotel Baron Indah, hotel Brothers, hotel Logi dan hotel Fave dengan jumlah peserta kurang lebih 2200 peserta yang kemudian dibagi perkelompok dan Rombel (Makruf, 2014).

Pelaksanaan PLPG setiap tahap dalam satu hotel Rombel dibagi perkelas. Setiap satu Rombel kelas terdiri atas 30 peserta, dan satu rombel untuk kelompok peerteaching/peerguidance terdiri atas 10 peserta. Jadi satu rombel dibagi lagi menjadi tiga kelas dalam kelompok peer-teaching/peer-guidance.

Dalam pelaksanaan PLPG kuota tambahan tahun 2013 di LPTK Rayon 232 FITK IAIN Surakarta semua peserta diasramakan dan mendapatkan bimbingan secara penuh dari para instruktur/asesor dengan harapan pelaksanaan PLPG dapat mencapai hasil output yang maksimal.

\section{Materi}

Materi PLPG disusun dengan memperhatikan empat kompetensi guru, yaitu: a) pedagogik; b) profesional; c) kepribadian; dan d) sosial. Standardisasi kompetensi yang dijabarkan dalam materi PLPG dikembangkan oleh LPTK penyelenggara sertifikasi dengan mengacu pada Permendiknas No. 16 Tahun 2007 tentang Standar Kualifikasi Akademik dan Kompetensi Guru. Sumber belajar pada PLPG dapat berupa buku, diktat, atau modul. Oleh karena pembelajaran dalam PLPG menuntut peserta untuk belajar secara mandiri, maka LPTK Rayon 232 
FITK IAIN Surakarta mengemas bahan ajar untuk peserta PLPG dalam bentuk modul yang didalamnya mencakup: Tujuan pembelajaran (kompetensi yang ingin dicapai), paparan materi, latihan-latihan, evaluasi, kunci jawaban, dan daftar Pustaka. (Makruf, 2014). Pada saat workshop, setiap kelas terdiri 30 peserta yang difasilitasi oleh dua orang instruktur/asesor yang memiliki NIA relevan.

\section{Proses Penilaian}

Proses penilaian kegiatan PLPG pada guru kelas MI kuota tambahan tahun 2013 dilaksanakan dalam tiga bentuk, yaitu: pertama, penilaian produk workshop yang dilaksanakan selama proses kegiatan PLPG berlangsung, penilaian ini diberikan kepada semua peserta PLPG guru kelas MI (Giyoto, Makruf, 2014). Penilaian ini dipilih oleh Rayon 232 untuk mengetahui kemampuan kreativitas guru dalam memecahkan masalah saat terjadi masalah dalam proses pembelajaran yang dilaksanakan guru di kelas, dimana para guru diwajibkan membuat PTK (penelitian tindakan kelas). Dalam penilaian ini instruktur dapat menilai dari beberapa unsur kompetensi, diantaranya: kepribadian, sosial, pedagogig dan profesional. Selain membuat PTK para guru juga membuat RPP dan LKS. Kedua penialian ini dimaksudkan untuk menilai kreativitas guru dalam mengembangkan bahan ajar dan mengembangkan objek ajar serta ketrampilan guru dalam membuat soal untuk siswa.

Kedua, penilaian ujian praktik, penilaian ujian praktik merupakan penilaian yang diberikan untuk menilai para guru dalam melaksanakan pembelajaran, yang dimulai dari persiapan pembelajaran, proses 
pembelajaran, penggunaan metode, tehnik, penggunaan media pembelajaran dan cara mengavaluasi sertata menilai. Panilaian ini dilaksanakan pada saat pendalaman materi atau kegiatan workshop sudah terlaksanakan semua, biasanya pada hari ketujuh dan delapan pelaksanaan kegiatan PLPG. Penilaian ini diikuti semua guru kelas MI, dimana masing-masing rombongan belajar terdiri dari 10 peserta dan masing-masing peserta melaksanakan praktik selama 1 jam pelajaran atau sama dengan 50 menit. Setiap guru maju menyerahkan RPP yang telah dibuat kepada instruktur, kemudian guru peserta mengajar sebagaimana biasanya mengajar dikelas dengan peserta didik teman peserta yang lain.

Dalam melaksanakan pembelajaran guru peserta tersebut harus sesuai dengan RPP yang diajukan kepada instruktur, dari mulai membuka, proses pelaksanaan pembelajaran dan menutup pembelajaran. Dalam pelaksanaan pembelajaran guru yang bersangkutan harus menggunakan media dan metode serta tehnik yang sesuai dengan materi yang disampaiakan, setelah selesai melaksanakan pembelajaran kemudian peserta lain dan instruktur memberi masukan dan menilai dengan menggunakan IPPP (Instrumen Penilaian Perencanaan Pembelajaran) dan penilaian pelaksanaan pembelajaran peer teaching (Giyoto, 2014). Penilaian ini dipilih dan diberikan guna menilai kompetensi pedagogik dan profesional guru, selain tersirat juga kompetensi kepribadian dan sosial. Penilaian ini dipilih karena dengan praktik langsung asesor/instruktur dapat mengetahui secara langsung 
kemampuan pedagogik guru kelas MI terutama dalam melaksanakan proses pembelajaran.

Ketiga ujian tertulis, ujian tertulis diberikan kepada para guru kelas MI dua kali, yaitu ujian local dan ujian nasional. Ujian local dilaksanakan malam hari " $H$ " dari hari terakhir dengan menjawab 5 soal uraian, soal yang diberikan menyangkut materi workshop yang diberikan. Soal ini dibuat tim yang telah ditunjuk oleh ketua Rayon 232. Evaluasi dan penilaian ini diberikan guna untuk mengetahui sejauh mana penangkapan dan pemahaman para guru kelas MI terhadap materi yang sudah disampaikan para instruktur selama beberapa hari sebelumnya. Dalam mengerjakan soal ini para guru kelas MI ditunggu dua instruktur, sehingga penilaian ini benar-benar obyektif, tidak ada rekayasa atau menyontek.

Penilaian post-test ini dipilih karena dianggap tepat untuk mengetahui output/hasil dari pendalaman materi yang dilakukan. Sedangkan ujian nasional dilaksanakan pada hari terakhir pelaksanaan kegiatan PLPG, para guru kelas MI pada ujian nasional mengerjakansoal 100 dengan rincian 95 soal pilihan ganda dan 5 soal uraian dengan waktu 120 menit atau sama dengan 2 jam. Naskah soal ujian tulis nasional terstandar secara nasional yang pengembangannya dikoordinasikan oleh KSG. Pelaksanaan uji tulis disesuaikan dengan rambu-rambu uji kompetensi. Penilaian ini di gunakan karena merupakan salah satu cara yang efektif untuk mengetahui kemampuan akademik peserta atau para guru kelas MI dalam menentukan kelulusan. Lebih lanjut pak Giyoto dan pak Imam Makruf menuturkan bahwa Ujian tulis bertujuan untuk 
mengungkap kompetensi professional dan pedagogik, sedangkan ujian kinerja untuk mengungkap kompetensi profesional, pedagogik, kepribadian, dan sosial secara holistik. Keempat kompetensi ini juga dinilai selama proses pelatihan berlangsung (Giyoto, 2014).

Ujian kinerja dilakukan dalam bentuk praktik pembuatan RPP, membuat PTK, pembuatan Lembar kerja Siswa (LKS) dan praktik penggunaan media pembelajaran serta praktik pembelajaran bagi guru atau mengajar.Ujian kinerja untuk praktik pembelajaran bagi guru atau mengajar setiap peserta minimal dilaksanakan selama 1JP atau selama 50 menit dengan ketentuan setiap peserta tampil dua kali, dan pada tampilan kedua merupakan ujian praktik. Tampilan pertama dan kedua untuk menilai kemampuan mengajar peserta.

\section{Bentuk Instrumen}

Bentuk instrument penilaian sertifikasi guru kelas MI kuota tambahan tahun 2013 yang telah dilaksanakan adalah diantaranya instrument penilaian perencanaan pembelajaran, instrument penilaian pelaksanaan pembelajaran peer teaching, instrument penilaian proses workshop, instrument penilaian proposal tindakan kelas, instrument penilaian rancangan bahan ajar, instrumen penilaian media pembelajaran, instrument penilaian lembar kerja siswa, dan instrument penilaian perangkat evaluasi, sebagaimana yang disajikan pada lampiran 3 sampai dengan 10 (Hafidah, 2013). Semua instrument ini digunakan karena memang sudah menjadi standart ketentuan oleh KSG dalam memberikan penilaian terhadap sertifikasi guru melalui kegiatan PLPG. Pelaksanaan 
penggunaan instrument ini menyesuai kandengan materi dan waktu pelaksanaan materi berlangsung.

Dari pengamatan peneliti dan dokumen-dokumen yang ada serta hasil wawancara, LPTK Rayan 232 baik statusnya sebagai institusi penyelenggara maupun dalam menyelenggarakan kegiatan PLPG sebagai penilaian sertifikasi guru, yang mulai dari persiapan, pelaksanaan UKA, pelaksanaan kegiatan PLPG hingga pada proses penilaiannya sudah baik dan sesuai dengan peraturan pemerintah dan rambu-rambu pelaksanaan PLPG yang diberikan oleh pemerintah melalui Kemendikbud Republik Indonesia.

\section{Target Keberhasilan}

\section{Target Minimal}

Target minimal LPTK Rayon 232 FITK IAIN Surakarta dalam melaksanakan kegiatan PLPG sertifikasi guru kelas MI kuota tambahan tahun 2013 menurut $\mathrm{Hj}$. Hafidah antara lain: Terbangunnya mental guru dalam melaksanakan pembelajaran; Dapat memberi pengalaman mengajar dengan sistem pembelajaran aktif kepada para guru; Guru dapat terdidik melaksanakan tugas dengan sepenuh hati; Guru mengetahui, memahami dan dapat mengoprasionalkan media pembelajaran dengan baik; Guru dapat meresapi profesi sebagai sebuah amanah untuk dipenuhi.Guru dapat mengenal perkembangan kurikulum terutama kurikulum 2013 yang terbaru (Hafidah, 2014). 


\section{Target Maksimal}

Target maksimal LPTK Rayon 232 FITK IAIN Surakarta dalam melaksanakan kegiatan PLPG sertifikasi guru kelas MI kuota tambahan tahun 2013 menurut $\mathrm{Hj}$. Hafidah antara lain: Dapat meningkatkan kompetensi guru; Guru dapat membuat RPP denagn benar dan dapat melaksakan PTK dengan baik; Guru dapat menguasai dan melaksanakan pembelajaran dengan kurikulum 2013; Guru dapat membuat media pembelajaran sederhana sendiri dengan microsoft office power point; Guru dapat membuat LKS sendiri; Guru dapat melaksakan pembelajaran berbasis saintifik dan paikem; Guru dapat melakukan penilaian otentik dengan benar; Semua Guru peserta dapat lulus PLPG dan mendapatkan sertifikat pendidik dengan hasil nilai yang maksimal menjadi guru tersertifikasi (Hafidah, 2014).

\section{Tantagan dan Hambatan}

Secara umum dalam melaksanakan kegiatan PLPG sebagai penilaian sertifikasi guru kelas MI tidak ada permasalahan menurut Bapak Giyoto selaku ketua Rayon 232, namun ada beberapa hal tehnis yang menjadikan tantangan dan hambatan para pelaksana kegiatan PLPG LPTK Rayon 232 (Giyoto, 2014).

Adapun tantangan dan hambatan tersebut antara lain: 1) pelaksanaan PLPG Kuota Tambahan Tahun 2013 merupakan kegiatan PLPG yang pertama kali diselenggarakan oleh LPTK Rayon 232 FITK IAIN Surakarta secara mandiri; 2) validasi data dari pemerintah yang kurang akurat dan selalu berubah-ubah mengganggu persiapan yang matang; 3) 
persiapan yang pendek untuk melakukan kegiatan, karena penunjukan dari pemerintah bersifat dadakan membuat kerepotan panitia dalam mempersiapkan segala sesuatu kebutuhan kegiatan; 4) komunikasi dengan peserta yang terlalu hitrogen dari hampir seluruh Kabupaten dan Kota di Jawa Tengah agak menghambat persiapan kegiatan; 5) jarak peserta dengan lokasi yang mayoritas jauh mempengaruhi tingkat komunikasi dan biaya pelaksanaan lebih mahal, dan; 6) permasalahan keuangan yang bermasalahnya rekening para peserta sehingga menghambat transferisasi dana kegiatan kerekening peserta dari pemerintah untuk di ambil pihak pelaksana berimbas pula pada terhambatnya penyelesaian pembiayayaan secara cepat. Namun dalam pelaksanaan hingga akhir kegiatan tidak ada permasalahan maupun hambatan (Giyoto, 2014).

\section{Persepsi Guru Peserta PLPG}

Berdasarkan hasil wawancara kepada Semua Guru Kelas MI Se Kecamatan Mejobo yang mengikuti sertifikasi kuota tambahan tahun 2013 Melalui PLPG di LPTK Rayon 232 IAIN Surakarta sejumlah 12 orang, semuanya menyatakan senang dan puas mengikuti PLPG yang diselenggarakan LPTK Rayon 232 IAIN Surakarta. Rasa senang dan puas menurutPak Yusuf, S.Pd.I guru MI NU Miftahut Tholibin yang menjadi salah satu peserta sertifikasi kuota tambahan tahun 2013 Melalui PLPG di LPTK Rayon 232 IAIN Surakarta adalah senang karena mendapatkan pengalaman dan banyak ilmu baru yang dapat membantunya ketika kembali ke satminkal dimana dia mengajar dan 
merasa puas atas pelayanan yang diberikan oleh LPTK Rayon 232 baik yang berkenaan dengan kebutuhan fisik, seperti: tempat tidurnya nyaman karena di hotel berbintang, menu makan dan snack selalu berganti-ganti sehingga tidak merasa bosan dan penyajiannya pun tidak pernah terlambat serta tidak dibatasi dalam mengambil makan, keperluan pribadipun mudah didapat di sekitar hotel karena hotel yang dipilih LPTK Rayon 232 sangat strategis, dan tenaga medis untuk memenuhi kebutuhan kesehatan juga ikut disiapkan oleh LPTK Rayon 232. Sedangkan kebutuhan non fisik, seperti: peralatan yang digunakan dalam kegiatan disediakan oleh LPTK Rayon 232, media pembelajaran dan kebutuhan materi juga disiapkan oleh LPTK Rayon 232 sebagai penyelenggara, kita tinggal belajar, berdiskusi, mengerjakan tugas-tugas terstruktur dibawah bimbingan para instruktur (Yusuf , 2014).

Sedangakan Ibu Dwi Astuti, S.Pd.I guru MI NU Suryawiyyah Kirig Mejobo Kudus yang juga peserta sertifikasi guru kelas MI kuota tambahan tahun 2013, mengemukakan hal senada, yaitu merasa senang mengikuti PLPG di LPTK Rayon 232 tahun 2013 karena mendapatkan banyak ilmu-ilmu baru yang selama ini belum ia dapat dan kuasai, selain itu tuturnya ia juga dapat banyak tukar pikiran tentang bagaimana cara mengajar yang baik dengan banyak orang dari berbagai daerah yang memiliki kebiasaan, budaya dan corak adat yang berbeda, sehingga sekaligus mendapatkan banyak saudara (Astuti, 2014).

Sepuluh peserta lainnya pun memiliki kesan yang serupa dengan yang dikemukakan pak Yusuf dan Ibu Dwi Astuti, mereka semua merasa 
senang dan puas karena mendapatkan banyak ilmu baru, teman dan saudara baru serta wacana dan motivasi baru.

\section{Penerapan Materi PLPG dalam Kegiatan Belajar Mengajar (KBM)}

Sebelum melakukan wawancara terlebih dahulu penulis melakukan observasi, Dari hasil observasi yang penulis lakukan mulai tanggal 23 Juni 2014 sampai dengan 21 Agustus 2014 penulis dapatkan bahwa dari 12 guru 7 diantaranya belum dapat membuat RPP dengan benar, kemudian 6 guru masih kurang persiapan dalam melakukan pembelajaran, dan sebagian besar guru masih menggunakan metode pembelajaran lama yang masih tersentral pada guru, yaitu banyak ceramah dan sedikit meningkatkan perkembangan potensi siswa walaupun ada yang sudah melakukan pembelajaran aktif (Observasi: 2014). Selain itu pembelajaran yang mengarah pada saintific dan penilaian secara otentik masih belum tersentuh, kebanyakan guru masih kebingungan dalam melakukan penilaian secara otentik yang benar (Astuti, 2014). Akan tetapi para guru sangat disiplin pada saat datang disekolah, yaitu semua guru yang penulis teliti 15 menit sebelum bel masuk sudah berada disekolah dan guru yang piket datang 30 menit sebelum bel masuk, selain itu para guru disiplin juga dalam masuk kelas melakukan pembelajaran dengan penuh tanggung jawab dan kejujuran (Astuti, 2014).

Dari hasil wanwancara kepada 12 guru kelas MI se Kecamatan mejobo yang mengikuti sertifikasi kuota tambahan tahun 2013 melalui PLPG di LPTK Rayon 232 FITK IAIN Surakarta tentang penerapan materi yang diterima pada kegiatan PLPG para guru menjelaskan bahwa 
untuk pembuatan RPP sudah mampu walaupun belum sempurna namun untuk pengimplementasiaannya masih kebingungan, Sedangkan untuk pembuatan PTK para guru masih banyak yang merasa belum bisa. Namun untuk penerapan pembelajaran menggunakan pendekatan scientifik dan PAIKEM hampir semua guru sudah menerapkan walau belum maksimal.

Pandangan Guru Kelas MI Terhadap Efektifitas Penilaian Sertifikasi Melalui Kegiatan PLPG

Dalam pembahasan efektifitas penilaian sertifikasi yang diberikan LPTK Rayon 232 FITK IAIN Surakarta melalui kegiatan PLPG kepada guru kelas MI peserta sertifikasi kuota tambahan tahun 2013 akan penulis paparkan satu persatu sesuai jawaban para guru kelas MI peserta sertifikasi kuota tambahan tahun 2013 kecamatan Mejobo, yaitu 12 guru kelas MI kecamatan Mejobo yang mengikuti penilaian sertifikasi guru kelas MI melalui PLPG kuota tambahan tahun 2013 di LPTK Rayon 232 FITK IAIN Surakarta menjelaskan sebenarnya penilaian sertifikasi guru kelas MI melalui PLPG sudah baik, karena banyak guru yang pada awal datangnya terlihat pasif, namun setelah mendapatkan materi dan seringnya berdiskusi dengan kawan-kawan guru dari daerah lain menjadi aktif dan kreatif pada waktu tampil Peer teaching workshop/latihan maupun praktik. Selain itu penilaian dalam kegiatan PLPG juga sudah mencakup berbagai aspek peilaian baik yang bersifat akademik maupun pedagogik dan meniali aspek kompetensi guru juga, yang meliputi: kompetensi pedagogik, kompetensi profesi, kompetensi kepribadian dan kompetensi sosial (Astuti, 2014). 
Kemudian menanggapi yang lebih efektif untuk memberikan penilaian sertifikasi guru kelas Mi selain melalui PLPG, 12 guru kelas MI kecamatan Mejobo yang mengikuti penilaian sertifikasi guru kelas MI melalui PLPG kuota tambahan tahun 2013 di LPTK Rayon 232 FITK IAIN Surakarta menjawab dengan jawaban yang sama, yaitu melalui PPG (Pendidikan Profesi Guru). karena PPG proses pembelajarannya lebih lama, kurang labih dua semester atau selama satu tahun yang logikanya pendalaman materinya pun akan semakin mendalam dan maksimal, bimbingan dan pelatihan dari para dosenpun akan semakin banyak dan mendalam, sehingga para guru akan menguasai materi dengan lebih baik dan dalam praktiknya pun akan lebih sempurna/maksiamal. Selain itu penilaian yang diberikan dan dilakukan instruktur juga akan lebih kompleks dengan waktu yang lebih panjang akan memperoleh hasil penilaian yang lebih baik.

Secara umum dari penelitian yang penulis lakukan melalui wawancara, pengamatan dan dokumentasi terjelaskan bahwa penilaian sertifikasi guru melalui PLPG pada guru kelas MI se Kecamatan Mejobo Kabupaten Kudus kuota tambahan tahun 2013 lebih tinggi nilai efektifitasnya dibandingkan nilai kurangnya. Setidaknya dengan kegiatan PLPG, para guru dapat meningkatkan kompetensinya, terbangun mental positifnya dalam melaksanakan pembelajaran dengan meresapi bahwa profesi itu adalah suatu amanah untuk dipenuhi sehingga dalam melaksanakan kegiatan pembelajaran akan melakukannya dengan sepenuh hati. 
Kurang Efektivnya Penilaian Sertifikasi Guru Kelas MI melalui PLPG

Dari hasil penelitian dilapangan baik secara observasi maupun wawancara yang penulis lakukan mengenai efektivitas penilaian sertifikasi guru kelas MI melalui PLPG pada guru kelas MI se Kecamatan Mejobo Kabupaten Kudus yang telah mengikuti PLPG kuota tambahan tahun 2013 di LPTK Rayon 232 FITK IAIN Surakarta sebenarnya dapat disimpulkan efektif. Kekurang efektivan penilaian sertifikasi guru kelas MI melalui PLPG pada guru kelas MI Kecamatan Mejobo Kabupaten Kudus yang telah mengikuti PLPG kuota tambahan tahun 2013 di LPTK Rayon 232 FITK IAIN Surakarta bila dicermati dari hasil observasi, dokumentasi dan wawancara sebenarnya hanya terkendala pada sisi teknis waktu pelaksanaan PLPG yang singkat dan penyampaian materi yang singkat juga karena faktor waktu, hal ini juga di pengaruhi faktor dimana guru kelas MI pada umumnya jarang mau untuk membaca buku, modul atau semacamnya yag berkaitan dengan pendidikan/pembelajaran sehingga dapat menjadi penambah rentetan kendala untuk mendukung keberhasilan penyampaian materi yang sangat singkat.

Kemudian hasil observasi dan wawancara di lapangan/Satminkal para guru mengajar kekurang efektivan penilaian serifikasi guru kelas MI melalui PLPG dikarenakan belum terpenuhinya faktor fasilitas penunjang implementasi materi yang didapat dari PLPG, faktor sarana prasarana yang urgen seperti buku kurikulum 2013, baik buku pembelajaran siswa maupun buku guru belum terdistribusikan sampai penelelitian ini penulis lakukan. 


\section{Simpulan}

Berdasarkan uraian di atas, maka penulis dapat menyimpulkan hasil penelitian yang penulis lakukan sebagai berikut: pertama, proses dan intstrumen penilaian sertifikasi guru kelas MI melalui PLPG pada guru kelas MI se Kecamatan Mejobo Kabupaten Kudus yang telah mengikuti PLPG di LPTK Rayon 232 IAIN Surakarta kuota tambahan tahun 2013 sudah terlaksanakan dengan baik dan sesuai dengan peraturan pemerintah serta rambu-rambu pelaksanaan PLPG yang diberikan oleh pemerintah melalui Kemendikbud Republik Indonesia. Kedua, pandangan guru kelas MI Se Kecamatan Mejobo Kabupaten Kudus yang telah mengikuti PLPG LPTK Rayon 232 IAIN Surakarta kuota tambahan tahun 2013 terhadap penilaian sertifikasi guru kelas MI melalui PLPG adalah sudah baik, karena banyak guru yang pada awal datangnya terlihat pasif kemudian menjadi aktif dan kreatif pada waktu tampil Peer teaching latihan maupun praktik. Selain itu penilaian dalam kegiatan PLPG juga sudah mencakup berbagai aspek peilaian, meliputi: kompetensi pedagogik, kompetensi profesi, kompetensi kepribadian dan kompetensi sosial.

Ketiga, Ketercapaian penilaian sertifikasi guru melalui kegiatan PLPG adalah dapat meningkatkan motivasi para guru dalam mengajar, membangun mental positif para guru dalam melaksanakan pembelajaran, meningkatkan kompetensi guru, guru terdidik melaksanakan tugas dengan sepenuh hati, dan guru dapat melaksanakn pembelajaran aktif. Keempat, Kurang efektifnya penilaian sertifikasi guru melalui kegiatan PLPG di LPTK Rayon 232 IAIN Surakarta kuota tambahan tahun 2013 adalah terkendala pada sisi teknis waktu pelaksanaan PLPG yang singkat 
sehingga berimbas pada kedalaman pemahaman guru terhadap materi yang diberikan, kemudian di lapangan/Satminkal para guru mengajar faktor terpenuhinya fasilitas, sarana prasarana dan biaya yang digunakan sebagai penunjang ketercapaian tujuan pembelajaran yang dirumuskan belum terpenuhi, distribusi buku kurikulum 2013 sebagai salah satu bahan ajar pokok proses pembelajaran belum terdistribusikan sampai penelelitian ini penulis lakukan. Selain itu unsur biaya yang tersedia dan yang dimiliki oleh para guru sangat minim, sehingga belum dapat berbuat banyak untuk menyiapkan kebutuhan perlengkapan dan media pembelajaran secara maksimal.

\section{Daftar Pustaka}

Abdillah, P. (2008). Kamus Ilmiah. Surabaya: Arkola.

An-Nawawi, A. (1995). Pendidikan Islam di Rumah. Sekolah dan Masyarakat. terj. Sihabuddin. Jakarta: Gema Insani Press.

Arifin, N. (2013). Modul Pelatihan Peningkatan Kinerja Guru Kelas MI Dalam Pengaplikasian Kurikulum 2013. Kudus.

Arikunto, S. (2002). Prosedur Penelitian (Suatu Pendekatan Praktek). Jakarta: RinekaCipta.

Astuti, D. (t.t.). Wawancara Tentang Kesan Mengikuti PLPG di LPTK Rayon 232 IAIN Surakarta. Mejobo: MI Suryawiyyah, 25 Juni 2014, Pukul. 09.10 WIB.

Azra, A. (2002). Paradigma Baru Pendidikan Nasional (Rekontruksi dan Demokratisasi). Jakarta : Kompas.

Depdiknas. (2009). Buku I Pedoman Teknis Pelaksanaan Sertifikasi. Jakarta: Depdiknas.

Ditjen Dikdasmen. (2009). Data Statistik Hasil Seleksi Calon Guru Sertifikasi. Jakarta: Depdiknas.

Effendy, U. (1989). Kamus Komunikasi. Bandung: Mandar Maju. 
Jalal, F. \& Supriyadi. (2001). Reformasi Pendidikan dalam Konteks Otonomi Daerah. Yogyakarta: Adicita.

Mahmudi. (2010). Manajemen Kinerja SektorPublik. Semarang: Universitas Diponegoro.

Mahanani, A. (2011). Buku Pintar PLPG (Pendidikan dan Latihan Profesi Guru). Yogyakarta: Araska.

Mastuhu. (2004). Menata Ulang Pemikiran Sistem Pendidikan Nasional dalam Abad 21. Yogyakarta: UII Pers,

Mulyasa, E. (2002). Manajemen Berbasis Sekolah. Bandung: Remaja Rosda Karya.

Muhajir, N. (1996). Metode Penelitian Kualitatif. Yogyakarta: Rake Sarasin.

Moleong, L. J. (2010). Metode Penelitian Kualitatif. Bandung: Remaja Rosda Karya.

Muslich, M. (2007). Sertifikasi Guru Menuju Profesionalisme Pendidik. Jakarta: Bumi Aksara.

Panitia Sertifikasi Guru LPTK Rayon 232 IAIN Surakarta. (2013). Modul Pendidikan dan Latihan Profesi Guru (PLPG) Kelompok Guru Kelas MI. Surakarta: FITK IAIN Surakarta,

Pornomo, E., dkk. (2012). Penilaian Pembelajaran. Bandar Lampung: Universitas Lampung press.

Salinan Lampiran Permendiknas No. 35 Tahun 2010 tentang Petunjuk Teknis Pelaksanaan Jabatan Fungsional Guru dan Angka Kreditnya. 1 Desember 2010.

Sudjana, N. (2001). Prosedur Penelitian Kualitatif. Bandung: RemajaRosdakarya,

Surya, M. (2000). Aspirasi Peningkatan Kemampuan Profesional dan Kesejahteraan Guru, dalam Jurnal Pendidikan dan Kebudayaan. No. 021, tahun ke-5.

Susanto. (2004). Sistem Informasi Manajemen. Bandung: Unpad Press.

Tafsir, A. (1994). Ilmu Pendidikan dalam Perspektif Islam. Bandung: Remaja Rosda Karya.

Yamin, M. (2006). Sertifikasi Profesi Keguruan di Indonesia. Malang: IKIP Malang. 
Yusuf. Wawancara Tentang Kesan Mengikuti PLPG di LPTK Rayon 232 IAIN Surakarta. Mejobo: MI MiftahutTholibin, 25 Juni 2014. Pukul. 10.03 WIB

Zamroni. (2000). Paradigma Pendidikan Masa Depan. Yogyakarta: Adipura. 
Mudarrisa, Jurnal Kajian Pendidikan Islam, Vol. 8, No. 2, Desember 2016: 283-312 